ISSN 1392-3196 / e-ISSN 2335-8947

Zemdirbyste-Agriculture, vol. 101, No. 1 (2014), p. 19-26

DOI 10.13080/z-a.2014.101.003

\title{
The assessment of common mugwort (Artemisia vulgaris L.) and cup plant (Silphium perfoliatum L.) productivity and technological preparation for solid biofuel
}

\author{
Algirdas JASINSKAS ${ }^{1}$, Raminta SIMONAVIČIŪTE ${ }^{1}$, Gintaras ŠIAUDINIS ${ }^{2}$, \\ Inga LIAUDANSKIENE ${ }^{3}$, Šarūnas ANTANAITIS ${ }^{3}$, Marqus ARAK ${ }^{4}$, Jūri OLT \\ ${ }^{1}$ Aleksandras Stulginskis University, Institute of Agricultural Engineering and Safety \\ Studentu 15A, Akademija, Kaunas distr., Lithuania \\ E-mail: algirdas.jasinskas@asu.lt \\ ${ }^{2}$ Vèžaičiai Branch, Lithuanian Research Centre for Agriculture and Forestry \\ Gargždų 29, Vėžaičiai, Klaipėda distr., Lithuania \\ ${ }^{3}$ Institute of Agriculture, Lithuanian Research Centre for Agriculture and Forestry \\ Instituto 1, Akademija, Kèdainiai distr., Lithuania \\ ${ }^{4}$ Estonian University of Life Sciences, Institute of Technology \\ Kreutzwaldi 56, 51014 Tartu, Estonia
}

\begin{abstract}
The research was carried out to determine the effects of soil $\mathrm{pH}$ (or liming) and nitrogen $(\mathrm{N})$ fertilization on the common mugwort (Artemisia vulgaris L.) and cup plant (Silphium perfoliatium L.) dry mass (DM) yield, calorific value and mechanical properties. Field experiments were set up in 2008 in Western Lithuania on a naturally acid ( $\mathrm{pH}$ 4.2-4.4) moraine loam.

According to the averaged data of four experimental years, the highest DM yield $4100 \mathrm{~kg} \mathrm{ha}^{-1}$ of common mugwort was established in 2009, which significantly decreased in the subsequent years. And, conversely, the highest cup plant DM yield $17980 \mathrm{~kg} \mathrm{ha}^{-1}$ was obtained in 2011. An increase in soil $\mathrm{pH}$ from 4.2-4.4 up to 5.6-5.7, resulting from $6.0 \mathrm{t} \mathrm{ha}^{-1} \mathrm{CaCO}_{3}$ application, increased cup plant DM yield by $27.4 \%$. Fertilization with $120 \mathrm{~kg} \mathrm{ha}^{-1} \mathrm{~N}$ significantly increased common mugwort and cup plant DM yield by $34.5 \%$ and $26.7 \%$ respectively, compared with the treatment without $\mathrm{N}$ fertilization. We also studied the chopping quality of common mugwort and cup plant and chaff fractional composition using sieves with different mesh sizes. The chaff of cup plant was finer and more even, and thus more suitable for use for energy purposes. Plant milling quality showed cup plant particles to be smaller and more even too, and thus better suited for pressing and combustion. The highest calorific value of common mugwort (17.97 $\mathrm{MJ} \mathrm{kg}^{-1}$ ) was obtained in 2010 and that of cup plant (17.48 $\left.\mathrm{MJ} \mathrm{kg}^{-1}\right)$ in 2012. The calorific values of common mugwort and cup plant were influenced most by the year of cultivation and $120 \mathrm{~kg} \mathrm{ha}^{-1}$ $\mathrm{N}$ application.
\end{abstract}

Key words: annual dynamics, calorific value, dry mass, fractional composition, liming, nitrogen, soil pH.

\section{Introduction}

Biomass is one of the basic renewable sources in energy systems. Compared with fossil fuel, the use of plant-based bio-fuel significantly reduces the "greenhouse" effect; $\mathrm{CO}_{2}$ emission approximately equals zero, because the amount of $\mathrm{CO}_{2}$, which is released during combustion, is used for the production of organic material during photosynthesis. Currently, much attention is being focused on identifying suitable plant species, which can provide high-energy outputs, and could replace fossil fuel energy sources (Forsberg, 2000; McKendry, 2002). In recent years, in Lithuania as well as abroad, a particular attention has been paid to the local and introduced plant species with a high energy value, high terrestrial biomass productivity and high adaptation to growing under local soil and climate conditions (McKendry, 2002; Kryževičienè et al., 2010; Slepetys et al., 2012).

Artemisia genus is one of the biggest among Asteraceae family and is wide-spread in many countries. Several species are found in Lithuania (Galinis, 1980). Mostly mugwort has been studied as a medicinal plant and partly as a food plant. Due to a high essential oil concentration, caloric value of individual Artemisia species is quite high and can reach up to $4500 \mathrm{kcal} \mathrm{kg}^{-1}$ (Frandsen, 1983; Judžentienè, Buzelytė, 2006). It has 
been reported that common mugwort biomass structure and chemical composition are well suited for biofuel production and could be a reliable raw source for pellet and briquette production (Kryževičienè et al., 2010). However, the possible conversion of mugwort biomass to any sort of biofuel has not been investigated yet.

Cup plant (Silphium perfoliatum L.) as well as other Silphium genus species originates from Northern America (Huxley, 1992; Clevinger, Panero, 2000). Although it is listed as a potentially invasive species, some Silphium species (S. perfoliatum L., S. integrifolium Michx. and S. laciniatum L.) are characterised as high yielding crops (Margieva, 2006; Voigt et al., 2012); thus, have been broadly investigated as a potential source for animal nutrition (Kowalski, 2007; Lehmkuhler et al., 2007; Stepanov, Usenko, 2009). Yet, their prospects for animal feeding might be limited due to lower feeding value compared with maize, which is another traditional coarse stem species (Lehmkuhler et al., 2007). The recent focus has been targeted on a potential use of cup plant biomass for bio-fuel production. So far, such kind of experiments have been at initial stage and reliable data are scarce (Steininger, Holtinger, 2010; Frączek et al., 2011).

It is important to investigate not only cultivation peculiarities of these tall perennial grasses but also the technical measures of common mugwort and cup plant plant biomass preparation for biofuel, to assess quality indicators of these plants' chopping and milling, to determine the basic physical mechanical properties and calorific value of these plants biomass prepared for fuel. Some of these investigations have been done in other countries, but there is a lack of studies on these plants under Lithuanian climate conditions. The chaff quality of plant stems used for fuel has to meet the requirements of chaff burning chambers used in boiler-houses, chaff transportation equipment and storages (Vares et al., 2007). A high burning efficiency is produced in furnaces when chaff of required thinness is used.

The aim of this study was to assess the dependence of common mugwort and cup plant biomass productivity on soil $\mathrm{pH}$ and nitrogen fertilization and to evaluate physical-mechanical properties of the biomass.

\section{Materials and methods}

Research on common mugwort (Artemisia vulgaris L.) and cup plant (Silphium perfoliatum L.) was carried out at Vèžaičiai Branch of Lithuanian Research Centre for Agriculture and Forestry $\left(55^{\circ} 43^{\prime} \mathrm{N}, 21^{\circ} 27^{\prime} \mathrm{E}\right.$ on a naturally acid moraine loam (Eutri-Hypostagnic Albeluvisol, ABj-w-eu) during 2008-2012. In the spring of 2008, before the establishment of the experiments, the following characteristics of upper soil layer $(0-20 \mathrm{~cm})$ were determined: $\mathrm{pH}_{\mathrm{KCl}}$ 4.25-4.45, mobile $\mathrm{P}_{2} \mathrm{O}_{5}$ 35$120 \mathrm{mg} \mathrm{kg}^{-1}$, mobile $\mathrm{K}_{2} \mathrm{O} 140-209 \mathrm{mg} \mathrm{kg}^{-1}$, hydrolytic acidity 21.9-62.1 mequiv $\mathrm{kg}^{-1}$ and mobile Al 10.7$50.9 \mathrm{mg} \mathrm{kg}^{-1}$.

Field experiments were laid out in two-factorial arrangement. Factor A - lime fertilizers (0, 3.0 and $\left.6.0 \mathrm{t} \mathrm{ha}^{-1} \mathrm{CaCO}_{3}\right)$. The whole research area was divided into three different $\mathrm{pH}$ strips: 4.25-4.4 (natural acidity), 5.0-5.1 and 5.6-5.7. Factor B - nitrogen fertilization rates $\left(0,60\right.$ and $\left.120 \mathrm{~kg} \mathrm{ha}^{-1}\right)$. Nitrogen fertilization treatments were set out randomly with three replications in each $\mathrm{pH}$ strip. Lime material ("Opokos", Lithuania) was spread in April 2008, before the setting up the trial. Nitrogen fertilization (ammonium nitrate) was performed each year of the studies. Phosphorus (single superphosphate) and potassium (potassium chloride) fertilizers were applied before the establishment of the field studies in 2008. The rates of phosphorus and potassium fertilizers were equal for all the treatments $-60 \mathrm{~kg} \mathrm{ha}^{-1} \mathrm{P}_{2} \mathrm{O}_{5}$ and $60 \mathrm{~kg} \mathrm{ha}^{-1} \mathrm{~K}_{2} \mathrm{O}$.

Naturally grown up sprouts of common mugwort were used as planting material. The sprouts were planted on the $27^{\text {th }}$ of May in 2008. Cup plant seeds were sown in peat pots at the end of April. Cup plant seedlings at 2-3 leaf stage were planted in the trial site on the $3^{\text {rd }}$ of June 2008. The distance between the rows of common mugwort was $0.75 \mathrm{~m}$; the distance between plants in rows was $0.5 \mathrm{~m}$. The distance between the rows of cup plant was $1.0 \mathrm{~m}$; the distance between individual plants in each row was $0.5 \mathrm{~m}$. The harvested area of each plot of both crops was $10 \mathrm{~m}^{2}$. The yield estimation started in 2009 . Each year, in the second half of September, the biomass of common mugwort and cup plant was cut using a rotary reaper ("Claas", Germany). The productivity of the above-ground biomass was recalculated into the airdry mass (DM). For determination of plant chopping quality, common mugwort and cup plant biomass at first was chopped by a harvester's "Maral 125" ("Fortshritt", Germany) drum chopper with 8 blades at a speed of 913 revolutions per minute (Jasinskas et al., 2012). To prepare the mass for pellet production, the chaff was milled to small 1-2 mm particles by a mill "Retsch SM 200" ("Retsch", Germany).

The fractional composition of chaff and mill was determined with the CEN/TS 15149-1:2006 system, commonly employed in the European Union, using a vibratory device and sieves with different mesh sizes (Jasinskas et al., 2012). $400 \mathrm{~mm}$ diameter sieves were used, where sieves with round pore are put one on other (in the order from the top sieve): diameter of $63,45,16$, $8,3.15$ and $1 \mathrm{~mm}$. For determination of mill fraction composition, we used sieves with meshes to $2 \mathrm{~mm}$ diameter. Screening $5 \mathrm{~kg}$ sample with a special sieve shaker, the set of sieves are being rotated in semicircle for $3 \mathrm{~min}$ in the horizontal plane. The rest of the mass on the sieve is weighted and each fraction's part in percentage is calculated. Each experiment is repeated five times.

Calorific value was measured by a calorimeter C 2000 (IKA, Germany). The analysis was performed by the standard methodology (Vares et al., 2007; BS EN 14918:2009).

A three-way analysis of variance with three replications design was performed on the data of the following factors: cultivation year, soil $\mathrm{pH}$ and nitrogen rate, using analysis of variance (ANOVA) to determine significance at $95 \%$ probability level $\left(\mathrm{LSD}_{05}\right)$ (Tarakanovas, Raudonius, 2003). 


\section{Results and discussion}

Dry mass (DM) yield. According to average data of four years, the highest common mugwort aboveground dry mass yield was determined during the first harvest year (i.e. 2009) - on average $4100 \mathrm{~kg} \mathrm{ha}^{-1} \mathrm{DM}$ (Fig. 1). In the next two years, DM productivity decreased signally and in 2011 was only $3084 \mathrm{~kg} \mathrm{ha}^{-1}$ (or $25 \%$ less than in the first year). Again in 2012, DM productivity increased substantially up to $3581 \mathrm{~kg} \mathrm{ha}^{-1}$. The DM yield strongly correlated with the number of stems per plant.
The decrease of DM yield in 2010 and 2011 growing seasons can be related to a higher air temperature and lack of moisture in the topsoil during the period of intensive growth in late May - early June, when a share of already synthesized DM could be utilized for more intense respiration. These tendencies agree with the observations of other trials that the lack of soil moisture could substantially retard mugwort development and DM accumulation. Due to different growth conditions, the increment of DM can vary up to $31 \%$ (Kryževičienè et al., 2010).

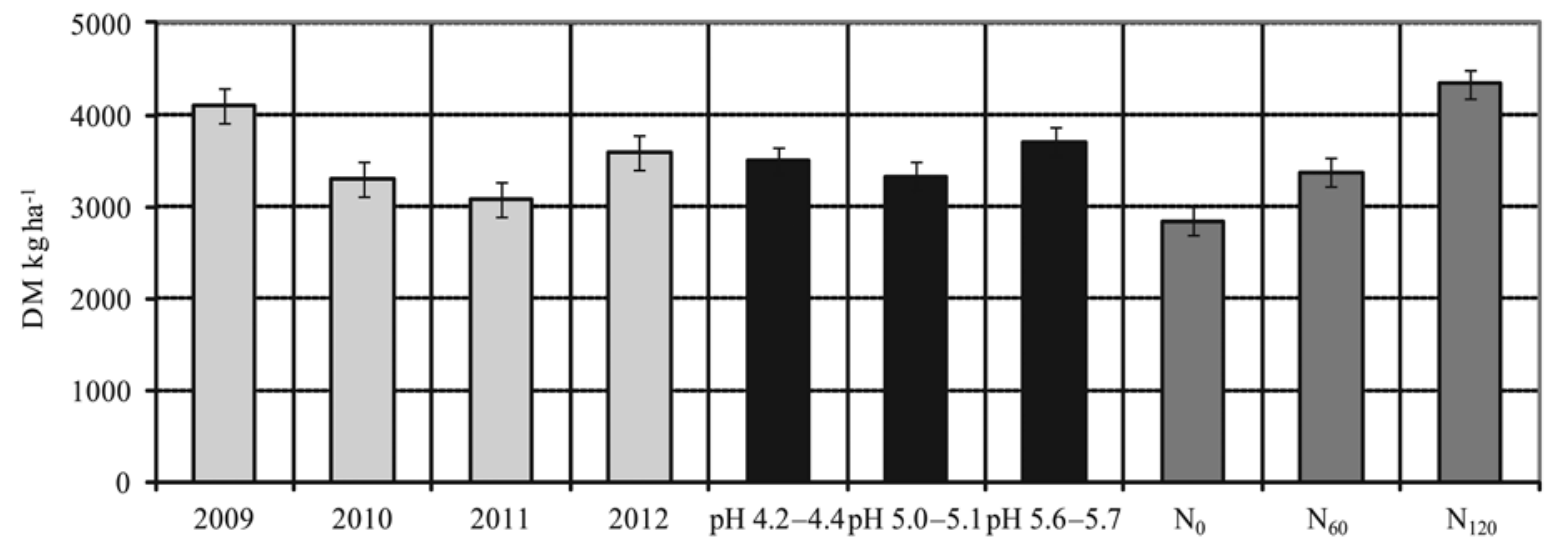

Figure 1. The influence of cultivation year, soil pH and nitrogen fertilizers on common mugwort (Artemisia vulgaris) dry mass (DM) yield

The cultivation of common mugwort under different soil $\mathrm{pH}$ (or liming) had no significant influence on biomass productivity. Common mugwort tolerates a wide range of soil types as well as soil acidity levels (Huxley, 1992). These studies also confirmed that liming of common mugwort crops is inexpedient. The common mugwort's DM yield, and at the same time the differences between particular treatments were determined by the nitrogen fertilization (especially $120 \mathrm{~kg} \mathrm{ha}^{-1}$ rate) - in this case, the DM increment was the highest and reached $4334 \mathrm{~kg} \mathrm{ha}^{-1}$, on average (or $34.5 \%$ more than without nitrogen fertilization). Similar tendencies were observed in parallel studies performed in Central Lithuania. By the application of $120 \mathrm{~kg} \mathrm{ha}^{-1} \mathrm{~N}$ rate, common mugwort achieved the highest DM yield at the second harvest year - $9038 \mathrm{~kg} \mathrm{ha}^{-1}$, on average (Kryževičienè et al., 2010). However, common mugwort productivity in subsequent years decreased sharply to average annual DM yield of $3400 \mathrm{~kg} \mathrm{ha}^{-1}$ (Slepetys et al., 2012). The cup plant DM productivity increased from $6746 \mathrm{~kg} \mathrm{ha}^{-1}$ in 2009 to $17980 \mathrm{~kg} \mathrm{ha}^{-1}$ in 2011 (the increase was 266\%) (Fig. 2). The use of lime fertilizers and the subsequent increase of soil $\mathrm{pH}$ to $5.6-5.7$ positively influenced the increase of DM from 11778 to $15005 \mathrm{~kg} \mathrm{ha}^{-1}$ (or $27.4 \%$ ). The application of nitrogen fertilizers had also a positive effect. Compared with the control treatment, $120 \mathrm{~kg} \mathrm{ha}^{-1}$ $\mathrm{N}$ fertilization significantly increased the DM yield from 11757 to $14897 \mathrm{~kg} \mathrm{ha}^{-1}$ (or $26.7 \%$ ).

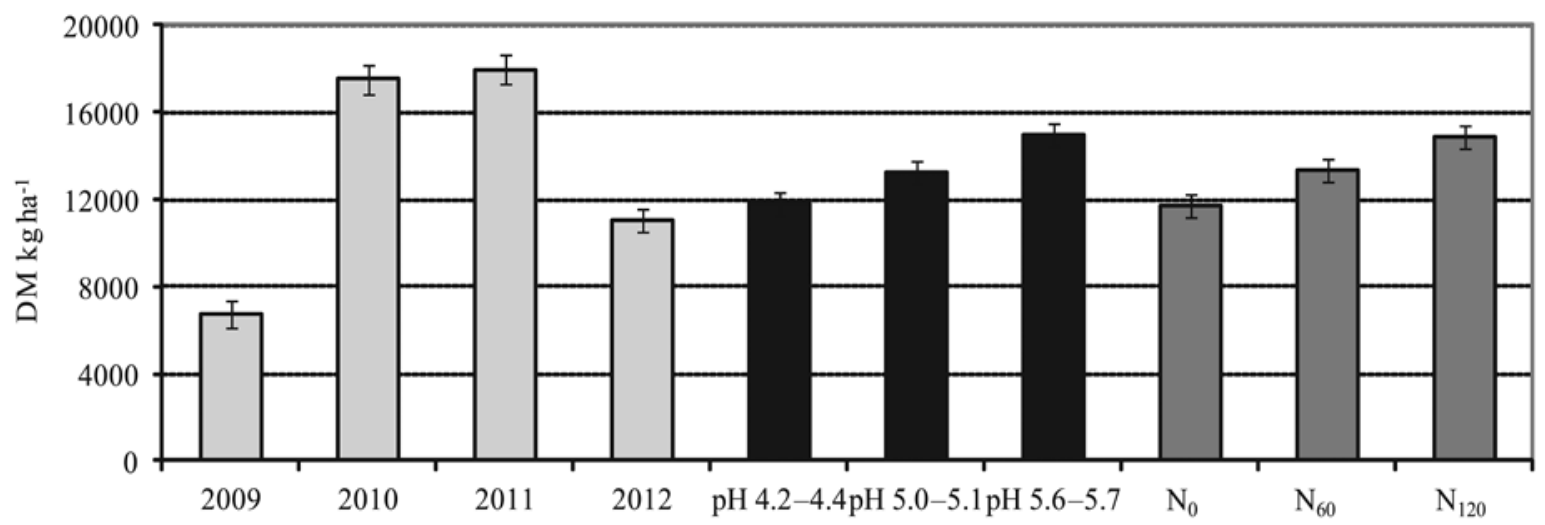

Figure 2. The influence of cultivation year, soil $\mathrm{pH}$ and nitrogen fertilizers on cup plant (Silphium perfoliatum) dry mass (DM) yield 
Cup plant is characterized by the dynamics of growth, when in the first year the yield is not very high, but it increases rapidly during the later years of growth (Filatov et al., 1986). Cup plant has a well developed deep rooting system. The roots are 30-150 cm long. Some roots grow down, others spread radially under soil surface (Stanford, 1990). Thus in our experiments, cup plant dependence on atmospheric precipitation was less obvious compared to common mugwort. Though cup plant is a species which produces high biomass yield, its productivity might be influenced by other biotic factors. Similar studies in Central Lithuania revealed that on Eutri-Cambic Arenosol (ARb-eu), which is less suited for many plants growing, under the application of $60 \mathrm{~kg} \mathrm{ha}^{-1}$ $\mathrm{N}$, the average annual cup plant productivity was $7290 \mathrm{~kg}$ DM ha ${ }^{-1}$. Cup plant productivity was somewhat lower than that of other coarse-stemmed species - Heliantus tuberosus, Sida hermaphrodita or Artemisia dubia (Slepetys et al., 2012). Whereas under Central Poland's growing conditions, which are defined as having higher sum of active temperatures and longer vegetation period, each year different species of Silphium can produce 17800-28800 kg ha-1 DM yield (by annual application of $100 \mathrm{~kg} \mathrm{ha}^{-1} \mathrm{~N}$ ) (Kowalski, 2004; 2007). The increment of cup plant DM was far greater in comparison with common mugwort. In separate years of studies, cup plant DM yield exceeded common mugwort DM yield by on average $58-583 \%$.

Chopping quality of energy plants. While assessing common mugwort and cup plant chopping quality we determined the fractional composition of chaff and mill. The dependence of plant chaff fractional composition $(\%)$ on the mesh diameter $(\mathrm{mm})$ of sieves is presented in Figures 3 and 4.

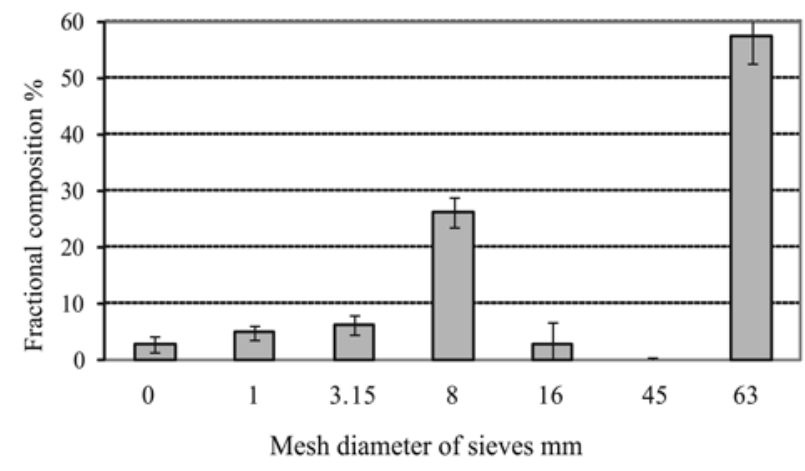

Figure 3. The dependence of common mugwort (Artemisia vulgaris) chaff fractional composition on the mesh diameter of sieves

The evaluation of plant stems chaff fractional composition according to the methodology applied in the EU countries, using sieves with different mesh diameters showed that the largest amount of cup plant chaff fraction accumulated on the sieve with round meshes of $8 \mathrm{~mm}$ diameter $-52.0 \pm 2.9 \%$ of all chaff mass. The largest amount of common mugwort chaff fraction accumulated

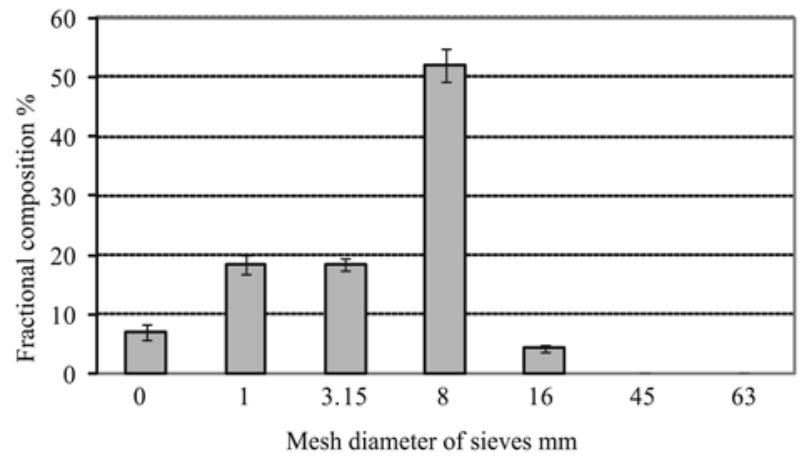

Figure 4. The dependence of cup plant (Silphium perfoliatum) chaff fractional composition on the mesh diameter of sieves

on the sieve with a mesh diameter of $63 \mathrm{~mm}-57.3 \pm$ $4.8 \%$. Cup plant chaff was finer and more even, and thus more suitable for use for energy purposes. For the pellet production the chaff was milled by a hammer mill. Milling quality was found similar to that of a drum chopper, when the mass fractional composition was determined using sieves with different mesh sizes. The dependence of plant mill fractional composition (\%) on the mesh diameter $(\mathrm{mm})$ of sieves is presented in Figures 5 and 6.

The evaluation of cup plant mill fractional composition using sieves with different mesh diameters

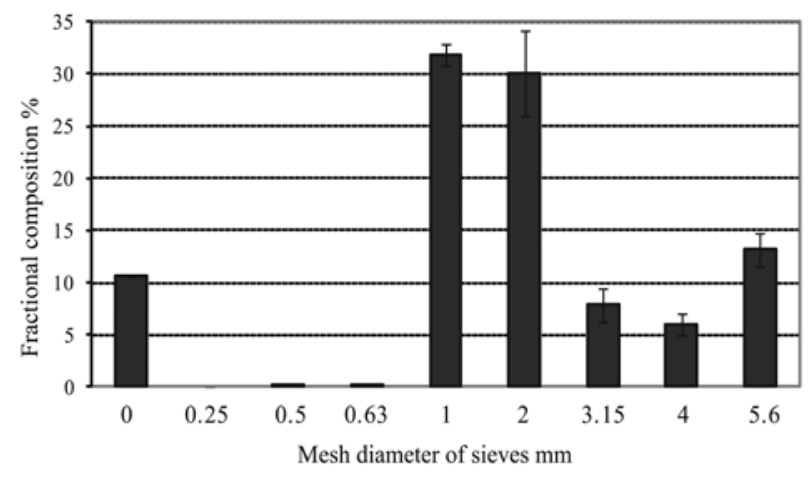

Figure 5. The dependence of common mugwort (Artemisia vulgaris) mill fractional composition on the mesh diameter of sieves

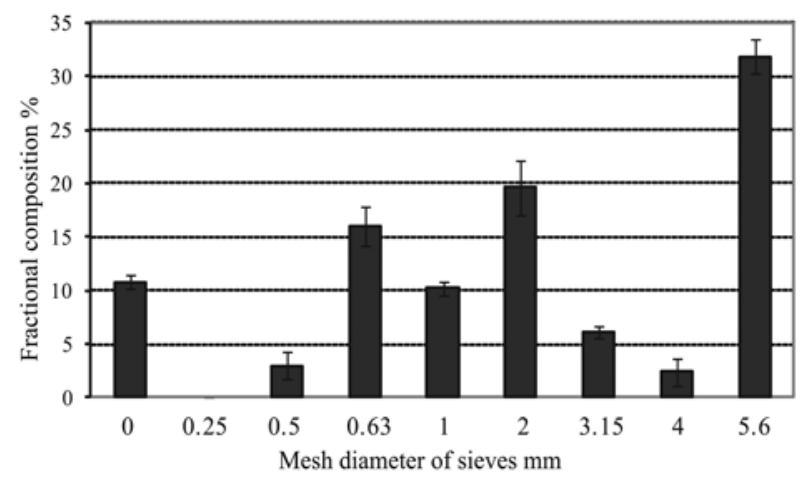

Figure 6. The dependence of cup plant (Silphium perfoliatum) mill fractional composition on the mesh diameter of sieves 
shows that the largest fraction of cup plant chaff was accumulated on the sieve with $5.6 \mathrm{~mm}$ mesh diameter by $31.8 \pm 1.6 \%$ of all fractional part. The meal was not accumulated on the sieve with 0.25 mesh $\mathrm{mm}$ diameter. From the chart on common mugwort mill fractional composition we can see that the largest fraction of mill was accumulated on the sieve with $1 \mathrm{~mm}$ holes $-31.8 \pm$ $0.0 \%$ of all fractional part, and a little less on the sieve with $2 \mathrm{~mm}$ holes $-30.1 \pm 4.1 \%$ of all fractional part. The meal was not accumulated on the sieves with 0.25 and $0.5 \mathrm{~mm}$ mesh diameter. Cup plant particles were found to be smaller and more even, because of which they were better suited for pelleting and usage for burning. Research results of common mugwort and cup plant pelleting and usage for energy purposes will be presented in a separate article.

Calorific value. Cultivation year was a significant factor for common mugwort calorific value, which ranged from $17.84 \mathrm{MJ} \mathrm{kg}^{-1}$ in 2011 to $17.97 \mathrm{MJ}$ $\mathrm{kg}^{-1}$ in 2010 (Fig. 7). Cultivation in soil with different $\mathrm{pH}$ level did not have a vital influence on the common mugwort biomass calorific value. A substantial and positive impact was obtained by nitrogen $120 \mathrm{~kg} \mathrm{ha}^{-1}$ fertilization - the biomass calorific value increased from 17.84 to $17.97 \mathrm{MJ} \mathrm{kg}^{-1}$. Thus, nitrogen fertilizers may have had a positive impact on the chemical composition of biomass and herewith on the calorific value.

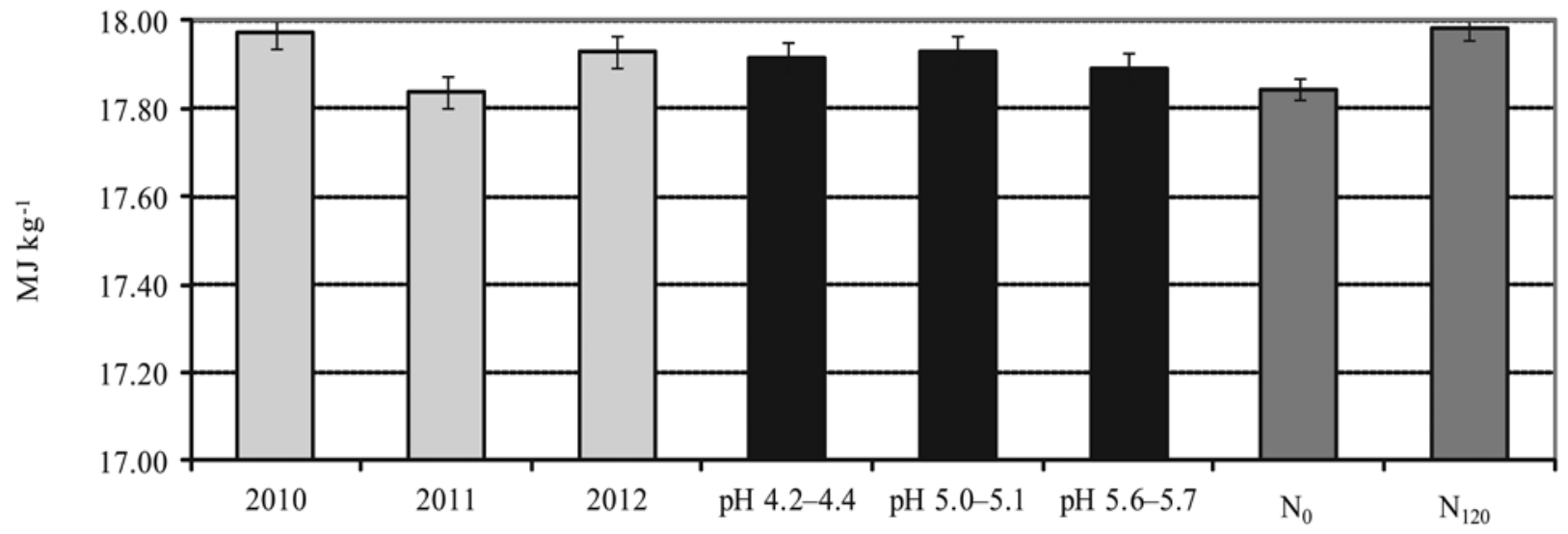

Figure 7. The influence of cultivation year, soil pH and nitrogen fertilizers on common mugwort (Artemisia vulgaris) calorific value

The growth conditions had a significant impact on cup plant calorific values (Fig. 8). In 2012, the average calorific value was $17.48 \mathrm{MJ} \mathrm{kg}^{-1}$. Compared with the results of the previous two-years, the increase of calorific value was significant. The calorific value of cup plant, grown under different $\mathrm{pH}$ backgrounds, ranged from 17.26 to $17.35 \mathrm{MJ} \mathrm{kg}^{-1}$. Although less notable, but there was observed a tendency that when growing cup plant in limed site (or when pH 5.6-5.7), its biomass calorific value was higher.

With liming, the nutrient stocks, soil $\mathrm{pH}$, organic carbon content increase in the plant rooting zone, in turn, the resorption of individual nutrients (including nitrogen) increases (Repšienè, 2003; Karcauskiene, Repsiene, 2009). It follows thence that the changes of the ratio of chemical compounds in above-ground biomass may change calorific value as well.

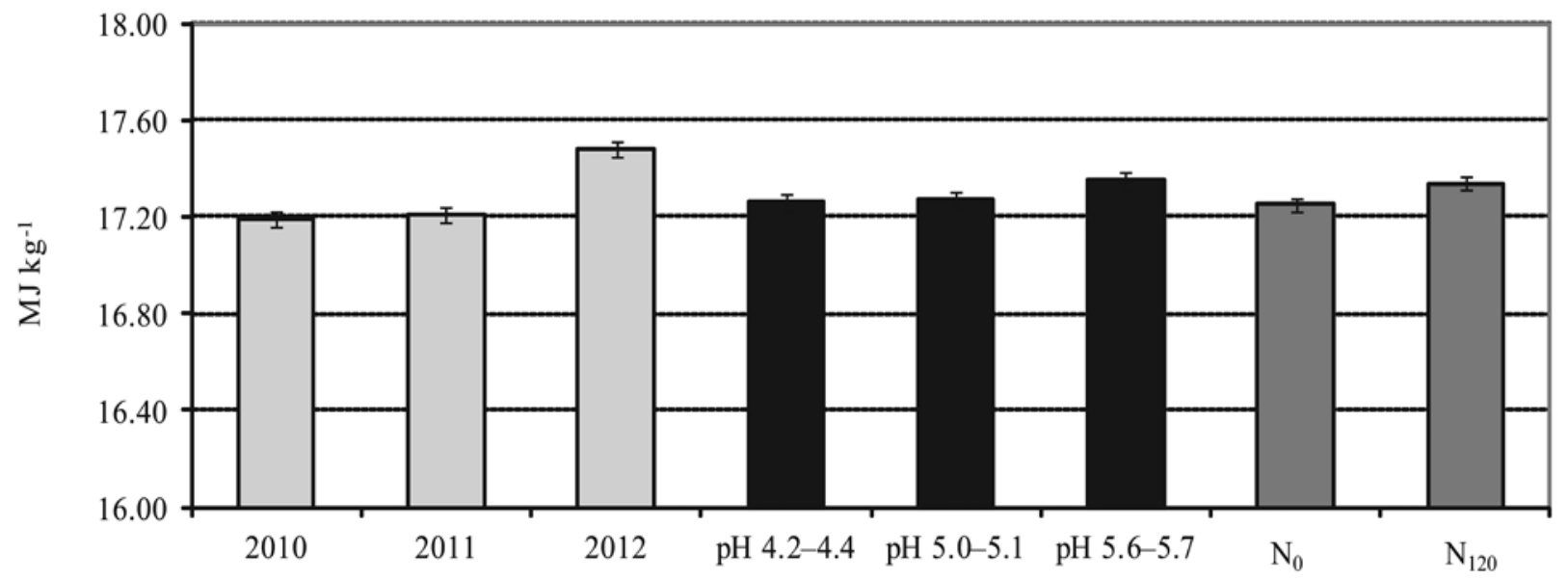

Figure 8. The influence of cultivation year, soil pH and nitrogen fertilizers on cup plant (Silphium perfoliatum) calorific value 
The use of $120 \mathrm{~kg} \mathrm{ha}^{-1} \mathrm{~N}$ rate notably increased the calorific value in cup plant biomass from 17.25 to $17.34 \mathrm{MJ} \mathrm{kg}^{-1}$. A positive influence of nitrogen fertilizers on calorific value was determined in all three experimental years. Nevertheless, our data do not agree with the conclusions of some authors, that nitrogen fertilizer does not affect the calorific value of biomass (Ercoli et al., 1999; Lemus et al., 2008). The data of other scientific investigations revealed that the average cup plant calorific value varied from 17.30 to $17.90 \mathrm{MJ}$ $\mathrm{kg}^{-1}$ (Heneman, Červinka, 2007; Frączek et al., 2011). The data presented in the article suggest that compared with common mugwort, cup plant biomass had a lower calorific value, and due to much higher annual DM yield and better measured technical properties, it seems that cup plant biomass is more suitable for biofuel manufacturing. The limited research data showed that briquettes manufactured from cup plant biomass are characterised by very good qualitative parameters (Frączek et al., 2011). These authors suggest that due to high biomass productivity, cup plant could be a relevant species for biogas production comparable with maize. However, the investigations concerned with cup plant biomass availability for biogas production are still in initial stage and no reliable results have been obtained so far (Steininger, Holtinger, 2010; Voigt et al., 2012).

Thus, the experiments with these energy crops must be continued by focusing on agronomical as well as biomass energy parameters. A special attention should be given to the suitability of energy crops biomass for particular type of biofuel.

\section{Conclusions}

1. According to the results of the four experimental years, the highest common mugwort dry mass (DM) yield averaging $4100 \mathrm{~kg} \mathrm{ha}^{-1}$ was obtained in 2009. The application of $120 \mathrm{~kg} \mathrm{ha}^{-1} \mathrm{~N}$ rate substantially increased DM yield by $34.5 \%$. Soil $\mathrm{pH}$ (or liming) had no significant effect on DM increment of mugwort.

2. Cup plant reached the highest DM yield averaging $17980 \mathrm{~kg} \mathrm{ha}^{-1}$ in the third harvest year in 2011 . The rise of soil $\mathrm{pH}$ from 4.2-4.4 to 5.6-5.7 (by application of $6.0 \mathrm{t} \mathrm{ha}^{-1} \mathrm{CaCO}_{3}$ ) and application of $120 \mathrm{~kg} \mathrm{ha}^{-1} \mathrm{~N}$ rate significantly and positively increased cup plant DM yield by $34.5 \%$ and $26.7 \%$, respectively.

3. Research results of plant chopping quality and chaff fractional composition showed that the largest amount of cup plant chaff fraction accumulated on the sieve with round meshes of $8 \mathrm{~mm}$ diameter $-52.0 \pm$ $2.9 \%$ of all chaff mass. The largest amount of common mugwort chaff fraction accumulated on the sieve with the $63 \mathrm{~mm}$ mesh diameter $-57.3 \pm 4.8 \%$. Cup plant chaff was finer and more even and thus was more suitable for use for energy purposes.
4. Research results on the milling quality of the tested plants showed that the cup plant particles were smaller and more even and thus were better suited for pelleting and usage for burning.

5. The highest calorific value of common mugwort (17.97 $\left.\mathrm{MJ} \mathrm{kg}^{-1}\right)$ was obtained in 2010 and that of cup plant (17.48 $\left.\mathrm{MJ} \mathrm{kg}^{-1}\right)$ in 2012. The calorific values of both plants notably varied in response to cultivation year and $120 \mathrm{~kg} \mathrm{ha}^{-1} \mathrm{~N}$ application.

\section{Acknowledgements}

The study was conducted while implementing the long term program "Plant biopotential and quality for multifunctional use".

Received 15022013

Accepted 23112013

\section{References}

BS EN 14918:2009. Solid biofuels. Determination of calorific value

CEN/TS 15149-1:2006. Solid biofuels. Methods for the determination of particle size distribution. Part 1: Oscillating screen method using sieve apertures of 3.15 $\mathrm{mm}$ and above

Clevinger J. A., Panero J. L. 2000. Phylogenetic analysis of Silphium and subtribe Engelmanninae (Asteraceae: Heliantheae) based on ITS and ETS sequence data. American Journal of Botany, 87 (4): 565-572 http://dx.doi.org/10.2307/2656600

Ercoli L., Mariotti M., Masoni A., Bonaria E. 1999. Effect of irrigation and nitrogen fertilization on biomass yield and efficiency of energy use in crop production of Miscanthus. Field Crops Research, 63: 3-11 http://dx.doi.org/10.1016/S0378-4290(99)00022-2

Filatov V. I., Bakalov A. M., Lavrov B. V., Komyagin N. A. 1986. Productivity of Silphium perfoliatum as a function of agricultural technology practices on ameliorated soils. Biological Abstracts, 82 (6): 58-63

Forsberg G. 2000. Biomass energy transport - analysis of bioenergy transport chains using life cycle inventory method. Biomass and Bioenergy, 19: 17-30 http://dx.doi.org/10.1016/S0961-9534(00)00020-9

Frączek J., Mudryk K., Wrobel M. 2011. Cup plant Silphium perfoliatum L. - biomass source for biofuels production. Inżynieria Rolnicza, 6 (131): 21-27 (in Polish)

Frandsen W. H. 1983. Modeling big sagebrush as a fuel. Journal of Range Management, 36 (5): 596-600 http://dx.doi.org/10.2307/3898349

Galinis V. 1980. Kiečiai. Natkevičaitè-Ivanauskienė M. et al. (eds). Lietuvos TSR flora, 6: 115-128 (in Lithuanian)

Heneman P., Červinka J. 2007. Energy crops and bioenergetics in the Czech Republic. Agriculture (Agricultural Engineering), 51: 73-78

Huxley A. 1992. The new RHS dictionary of gardening. London, UK, $3000 \mathrm{p}$. 
Jasinskas A., Ulozevičiūtė I., Šarauskis E., Sakalauskas A. 2012. Impact of immature willows stems chopping quality on the harmful emissions evaluation. Agronomy Research, 10 (spec. iss. 1): 75-84

Judžentienė A., Buzelytė J. 2006. Chemical composition of essential oils of Artemisia vulgaris L. (mugwort) from North Lithuania. Chemistry, 17 (1): 12-15 (in Lithuanian)

Karcauskiene D., Repsiene R. 2009. Long-term manuring and liming effect on moraine loam soil fertility. Agronomy Research, 7 (spec. iss. 1): 300-304

Kowalski R. 2004. Growth and development of Silphium integrifolium in the first 3 years of cultivation. New Zealand of Crop and Horticultural Science, 32: 389-395 http://dx.doi.org/10.1080/01140671.2004.9514320

Kowalski R. 2007. Silphium trifoliatum L. - a new alternative cultivation herbal plant? Acta Agriculturae Scandinavica, Section B: Soil and Plant Science, 57 (2): 155-166 http://dx.doi.org/10.1080/09064710600766503

Kryževičienė A., Šarūnaite S., Stukonis V., Dabkevičius Z., Kadžiulienè Ž. 2010. Assessment of perennial mugwort (Artemisia vulgaris L. and Artemisia dubia Wall.) potential for biofuel production. Žemès ūkio mokslai, 17 (1-2): 32 40 (in Lithuanian)

Lehmkuhler J. W., Ramos M. H., Albrecht K. A. 2007. Cupplant silage as a replacement for corn silage in growing beef cattle diets. Forage and Grazinglands DOI: 10. 1094/FG2007-1107-RS

Lemus R., Brummer C. E., Burras C. L., Moore K. J., Barker M. F., Molstad N. E. 2008. Effects of nitrogen fertilization on biomass yield and quality in large fields of established switchgrass in southern Iowa, USA. Biomass and Bioenergy, 32 (12): 1187-1194 http://dx.doi.org/10.1016/j.biombioe.2008.02.016

Margieva F. T. 2006. The results of the introduction of cup plant as a forage crop in North Ossetia, Russia: doctoral thesis, Gorsky State Agrarian University. Vladikavkaz, Russia (in Russian)

McKendry P. 2002. Energy production from biomass. Part 1. Overview of biomass. Bioresource Technology, 83: 37-46 http://dx.doi.org/10.1016/S0960-8524(01)00118-3

Repšiene R. 2003. The efficiency of placement and broadcast fertilization on the crop rotation yield on the acid and limed soil. Zemdirbyste-Agriculture, 84 (4): 63-82 (in Lithuanian)

Slepetys J., Kadziuliene Z., Sarunaite L., Tilvikiene V., Kryzeviciene A. 2012. Biomass potential of plants grown for bioenergy production. International scientific conference Renewable Energy and Energy Efficiency. Jelgava, Latvia, p. 66-72

Stanford G. 1990. Silphium perfoliatum (cup-plant) as a new forage: proceedings of the $12^{\text {th }}$ North American Prairie Conference. Cedar Falls, USA, p. 33-38

Steininger K., Holtinger S. 2010. Assessment of the regional biomass potential for the region East Styria. Wegener Center for Climate and Global Change. Final Report. $<$ http://www.central2013.eu> [accessed 2108 2013]

Stepanov A. F., Usenko A. V. 2009. Productivity of silphium depending on terms and height of cutting. Kormoproizvodstvo, 8: 25-26 (in Russian)
Tarakanovas P., Raudonius S. 2003. Statistic analysis of agronomical research data with computer programs ANOVA, STAT, SPLIT-PLOT from packet SELEKCIJA and IRRISTAT. Lithuanian University of Agriculture, $58 \mathrm{p}$. (in Lithuanian)

Vares V., Kask U., Miuste P., Pihu T., Soosaar S. 2007. Manual for biofuel users. Tallinn University of Technology, $178 \mathrm{p}$.

Voigt T. B., Lee D. K., Kling G. J. 2012. Perennial herbaceous crops with potential for biofuel production in the temperate regions of the USA. CAB Reviews, 7 (15): 1-13 http://dx.doi.org/10.1079/PAVSNNR20127015 
ISSN 1392-3196 / e-ISSN 2335-8947

Zemdirbyste-Agriculture, vol. 101, No. 1 (2014), p. 19-26

DOI 10.13080/z-a.2014.101.003

\title{
Paprastojo kiečio (Artemisia vulgaris L.) bei geltonžiedžio legèsto (Silphium perfoliatum L.) produktyvumo ir kietojo kuro ruošimo technologinis vertinimas
}

\author{
A. Jasinskas ${ }^{1}$, R. Simonavičiūtè $\dot{1}^{1}$, G. Šiaudinis ${ }^{2}$, I. Liaudanskienè ${ }^{3}$, Š. Antanaitis ${ }^{3}$, \\ M. Arak ${ }^{4}$, J. Olt ${ }^{4}$
}

${ }^{1}$ Aleksandro Stulginskio universiteto Žemès ūkio inžinerijos ir saugos institutas

${ }^{2}$ Lietuvos agrarinių ir miškų mokslų centro Vėžaičių filialas

${ }^{3}$ Lietuvos agrarinių ir miškų mokslų centro Žemdirbystės institutas

${ }^{4}$ Estijos gyvybès mokslų universiteto Technologijos institutas

\section{Santrauka}

Tyrimai atlikti siekiant nustatyti dirvožemio pH (arba kalkinimo) ir tręšimo azoto trąšomis įtaką paprastojo kiečio (Artemisia vulgaris L.) ir geltonžiedio legèsto (Silphium perfoliatum L.) sausosios masès (SM) derliui, šilumingumui ir mechaninėms savybèms. Lauko bandymai ịrengti $2008 \mathrm{~m}$. Vakarų Lietuvoje, natūraliai rūgščiame (pH 4,2-4,4) moreniniame priemolyje.

Remiantis vidutiniais ketverių metų tyrimų duomenimis, kiečių didžiausias SM derlius buvo nustatytas 2009 m. $4100 \mathrm{~kg} \mathrm{ha}^{-1}$, kuris esmingai sumažèjo vėlesniais tyrimų metais, o legėstų didžiausias SM derlius buvo gautas 2011 m. - vidutiniškai $17980 \mathrm{~kg} \mathrm{ha}^{-1}$. Dirvožemio $\mathrm{pH}$ padidejjimas nuo 4,2-4,4 iki 5,6-5,7 (pakalkinus 6,0 t ha-1 $\mathrm{CaCO}_{3}$ ) legèstų SM prieaugi padidino 27,4 \%. $120 \mathrm{~kg} \mathrm{ha}^{-1} \mathrm{~N}$ trąšų panaudojimas iš esmès padidino bendrą kiečių ir legèstų SM derlių - atitinkamai 34,5 ir 26,7 \% daugiau nei netręšiant. Tirta paprastųų kiečių ir geltonžiedžių legèstų smulkinimo kokybe bei pjaustinio frakcinè sudètis pagal Europos Sajungos šalyse taikomą metodiką, naudojant sietus su skirtingo skersmens skylutemis. Nustatyta, kad geltonžiedžių legėstų pjaustinys buvo smulkesnis ir tolygesnis, labiau tinkantis naudoti energetinėms reikmėms. Vertinant tirtų augalų malimo kokybę nustatyta, kad geltonžiedžių legèstų miltų dalelès buvo smulkesnès ir tolygesnès, todėl šie augalai labiau tinka presuoti ir naudoti deginimui. Didžiausias vidutinis paprastujjų kiečių biomasės šilumingumas siekè 17,97 $\mathrm{MJ} \mathrm{kg}^{-1}$ (2010 m.), o geltonžiedžių legèstų - 17,48 $\mathrm{MJ} \mathrm{kg}^{-1}$ (2012 m.). Abiejų augalų šilumingumo reikšmėms didžiausią ịtaką turèjo augimo metai ir $120 \mathrm{~kg} \mathrm{ha}^{-1}$ azoto trąšu panaudojimas.

Reikšminiai žodžiai: azotas, dirvožemio pH, frakcinė sudètis, kalkinimas, sausoji masè, šilumingumas, tręšimas. 